\title{
Interpretation of Maharaja Ranjit Singh in Portraiture: An Overview
}

\author{
Gurdeep Kaur \& Rohita Sharma \\ Department of Business and fine arts, Lovely Professional University, Phagwara, Punjab, \\ India.Email: gurdeepkaurı1@yahoo.in
}

\begin{abstract}
The influential popularity of Maharaja Ranjit Singh was too vast in his lifetime, that no one could remained detached from him. There are numerous portraits of Maharaja Ranjit Singh in various postures wearing different attires. This paper is an analysis of the presentation of the identity of Sikh Maharaja; Maharaja Ranjit Singh, recognized and grasped by the native painters. The study also focuses on postures and gestures captured by the painters with the inspirations of common-popular knowledge about the behaviors and lifestyle of Sikh Maharaja in Punjab Plains during first half of nineteenth century. This paper is also an attempt to grasp the lifestyle of Maharaja and role of his companions in the entirety of Maharaja Ranjit Singh through data analysis and reviewing the literature and memoirs of European travelers, which is also the base of data analysis. The study is based on explorative method. The study concludes that the interpretation of Maharaja Ranjit Singh through portraiture is the tremendous combination of facts and imaginations of native painters in various native styles combining and adjusting western influences.
\end{abstract}

Key words: Posture, gesture, seated, equestrian, face, dress.

\section{Introduction:}

Sikhs have no myths and divinities, so the painters focused on the art of portraiture in Punjab Plains during the Sikh dominance in the first half of nineteenth century. Various series of portraits emerged through the hands of painters for their Sikh patrons. There are numerous portraits are existed of Maharaja Ranjit Singh in different postures and gestures on different occasions, like seated on chair or stool or carpet involving in assemblies, relaxing with a beautiful lady inside his palace or any terrace or camp under a canopy as well as mounted on a stallion or elephant for inspecting his troops inside his kingdom. Although Maharaja Ranjit Singh hesitated of portraying himself, but there are numerous portraits of Maharaja were done by native Pahari Hindu-Muslim traditional painters in their Indian miniature style as well as by the native and European painters in their realistic European and company style. In Indian traditional style of portraiture; full-body portraits were done by native painters while, bust portraits were also included after European influences. This paper answers, why Maharaja often presented in some known significant postures and gestures at various junctures by the painters.

(C) AesthetixMS 2016. This Open Access article is published under a Creative Commons Attribution Non-Commercial 4.0 International License (http://creativecommons.org/licenses/by-nc/4.0/), which permits non-commercial re-use, distribution, and reproduction in any medium, provided the original work is properly cited. For citation use the DOI. For commercial re-use, please contact aesthetixms@gmail.com. 


\section{Postural variation in seated-portraits:}

\section{A. Varied kneeling postures}

While seated on carpet, golden-silver chairs and golden throne, Maharaja Ranjit Singh often shown in various kneeling postures. Maharaja was habitual of different comfortable postures. A group portrait of his early years; which is a record of Maharaja's meeting with Jaswant Rao Holkar in the year 1805 A.D, kneeling posture is used for Maharaja while seated on carpet (figure 1), while in his later portrait, he is shown seated on golden throne in kneeling posture (figure 2) but a little variation can be noticed in two kneeling postures. One (figure 1) is in kneeling posture but his feet remained crossed under him while seated on carpet, but in other (figure 2), kneeling posture is a popular posture of Indian miniature portraits. In figure 1 his raised hand shows his business in conversing, while in figure 2 his relaxing hands shows his old-aged comfort and peace among his courtiers as well as in figure 3 his habit of drinking was depicted by gestures of his hands, while relaxing on a chair. In another kneeling posture, one leg remained folded on knee and tucked under him and another leg remained raised on knee vertically (figure 3, 4). In another kneeling posture, Maharaja is depicted folded one leg on knee horizontally and one leg touches the ground (figure 5)

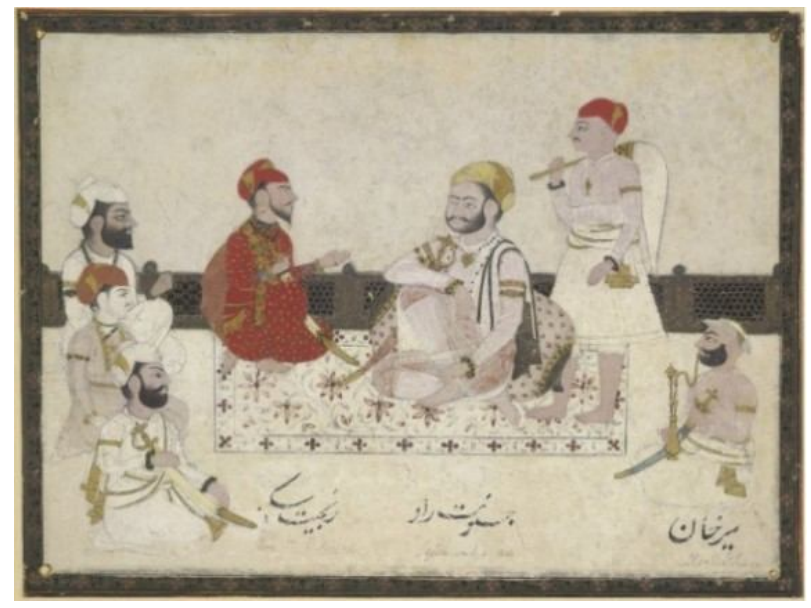

Figure 1. Maharaja's meeting with Jaswant Rao Holkar in the year 1805 A.D., Museum no. 1936, o411, o.1, British Museum

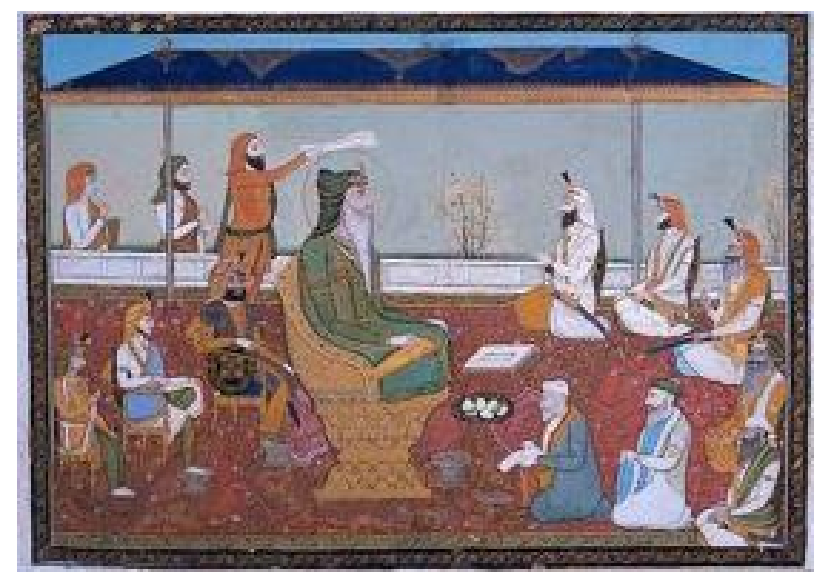

Figure 2. Ranjit Singh on his golden throne by Yechu Mussavir, C. 1830, museum no. 1990.1346, The San Diego Museum of art 


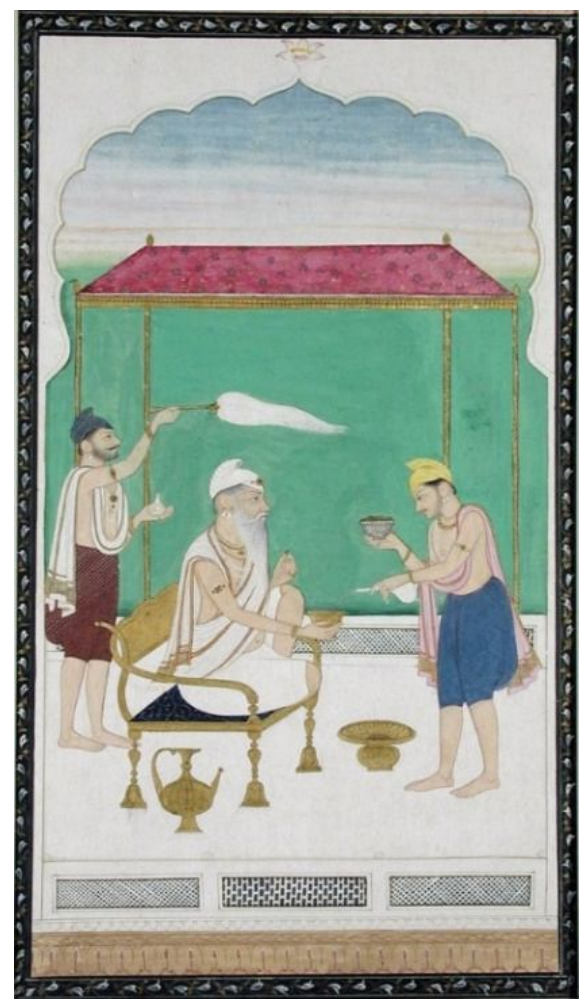

Figure 3. Ranjit Singh seated on a gold chair, attended by a morchal- bearer and served wine, Accession no. 1990.1345, The San Diego Museum of art

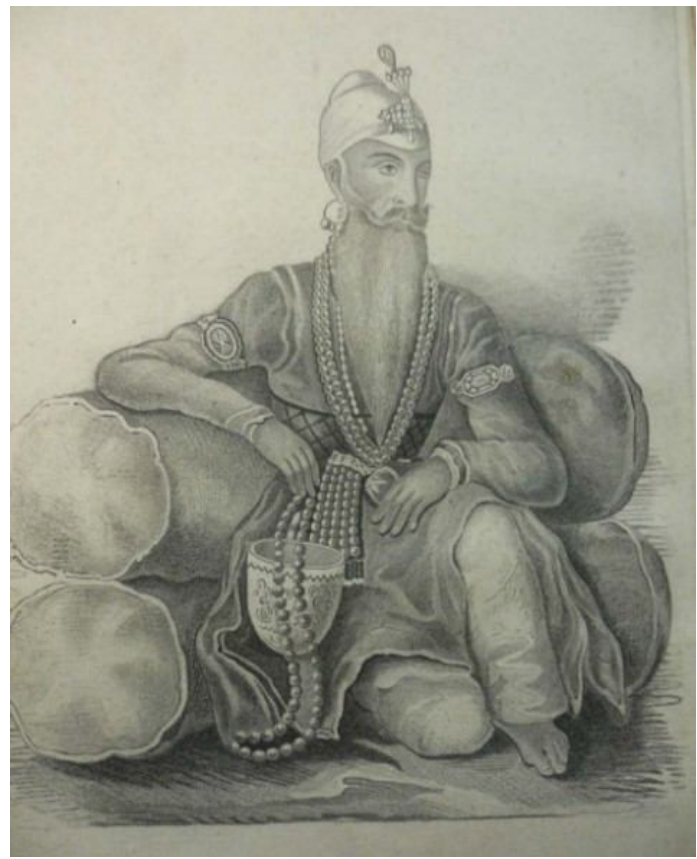

Figure 4. Maharaja Runjeet Singh from a portrait by Jewun Ram, Roopur in 1831. Lithograph by Kasinath after Jivan Ram, 1834. From H. T. Prinsep's Origin of the Sikh Power (Calcutta, 1834), frontispiece. 


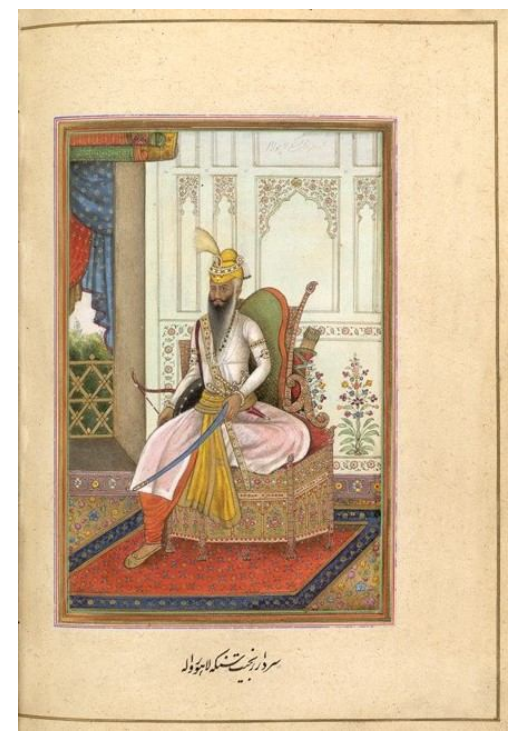

Figure 5. Shelf mark: Add. MS 27254, Item number: f.176v, Manuscript of 1830 . The album contains family biographies, in Persian, of princely families in the Sikh and Rajput territories by Colonel James Skinner (17781841), and 37 portraits of their current representatives

\section{B. Cross-legged posture}

The portraits of Maharaja after 1820-30, he is shown seated in a golden throne with his courtiers. Variation in Maharaja's favourite cross-legged postures are also observed by painters which reflected in portraits. Maharaja often shown in cross-legged sitting posture or asana popularly used in Indian ancient sculptures 'Maharajlilasana', in relaxing moods in which the body of a sitter remains in little leaning position and one leg remains on the other in cross-legged position and hands rest on thighs (figures $6,7,8$ ). Sometimes, both legs remain in cross posture resting on the chair (figure 7). It appears that Maharaja was habitual of comfortable postures while seated with his intimates and courtiers.

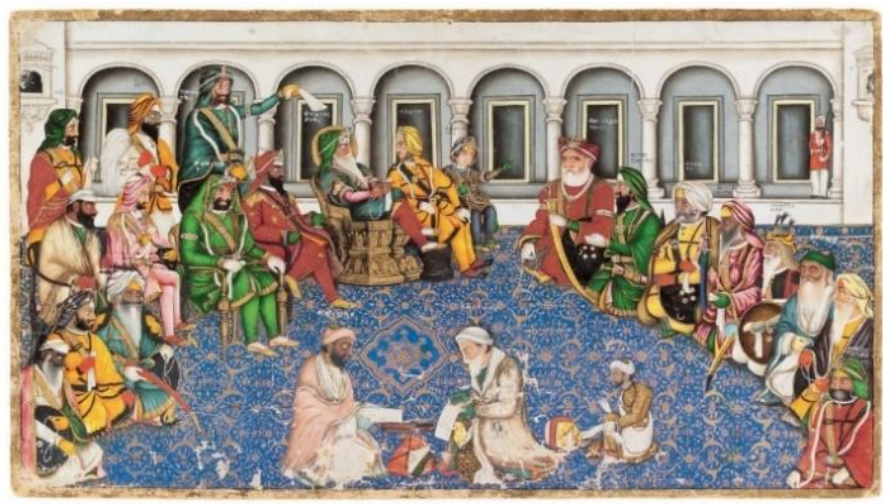

Figure 6. The Darbar of Maharaja Ranjit Singh, By- Hasan al Din, ca. 1850, Accession no. 1990.1351, The San Diego Museum of art

Maharaja preferred to sit 'Cross-legged in a golden chair'(Osborne 1840, 73) and 'sitting cross-legged in a large silver chair, very much resembling in shape what is called a hip bath' (Osborne 1840, 98- 99). 'When Ranjit Singh assumed the throne of the Punjab, it was not a throne in the literal sense that he sat upon. He turned down all suggestions about his sitting on the throne of the Mughal emperors and continued to hold durbar sitting cross-legged in one or other of the chairs in which he had sat as a chieftain and none of which had any resemblance to a royal 
throne. Sometimes he held durbar in an even more informal manner, sitting on a carpet and reclining on a velvet cushion. He was equally firm about adhering to his simple chieftain's turban without adding any royal emblem to it.' 'He (Maharaja) refused to sit on a throne and continued as before to hold durbar seated cross-legged in his little bathtub-like chair or, more often, received visitors in the oriental fashion reclining on cushions on a carpet.......These conventions were a complete departure from the accepted traditions of oriental courts..... ${ }^{\text {,ii }}$ ' $s i t$ with one foot in his hand, comfortably' (Eden 1866, 284)

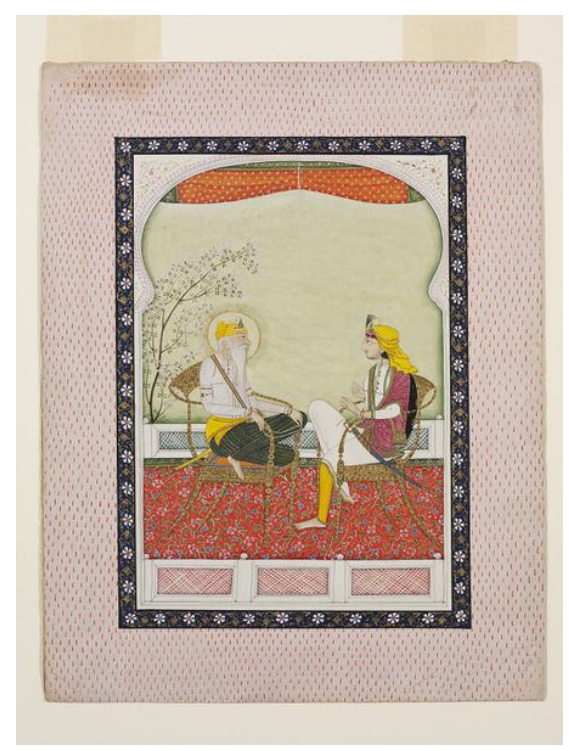

Figure 7. Ranjit Singh and Hira Singh, ca. 1838 - ca. 1840, Museum number: IS.114-1953, Victoria and Albert Museum

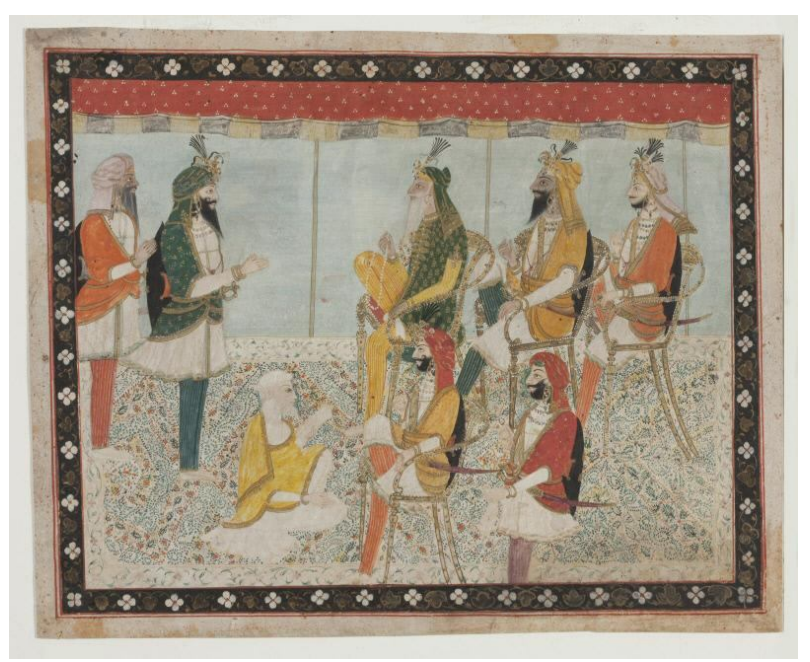

Figure 8. Maharaja Ranjit Singh and members of his court, C. 1825 A.D., museum no. 1998.97, Asian art museum of San Francisco

\section{Straight-legged posture}

Sometimes while seated on chair, Maharaja's legs remain straight (figure 9). His familiar posture of cross-legged sometimes changed and he sits on a chair or throne with straight legs downwards and both legs touch the ground and sometimes one leg or both remain resting on foot stool in 'lalîtâsana' position. 


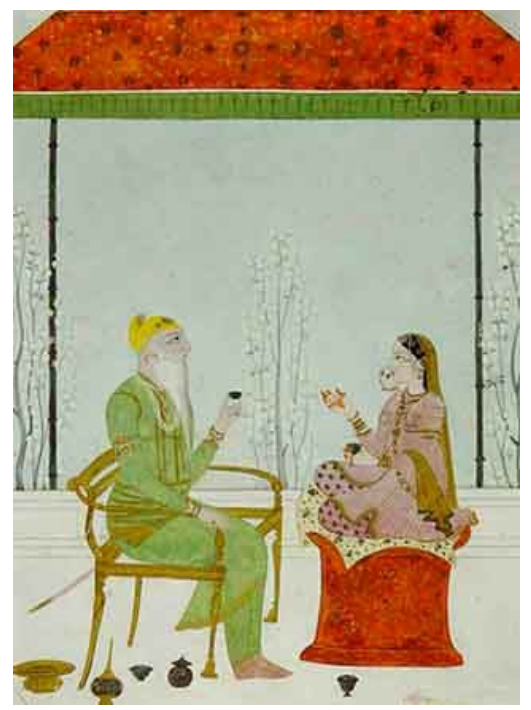

Figure 9. Maharaja Ranjit Singh, Indian museum, Calcutta

\section{Gestural variation in seated -portraits}

\section{A. Face}

Hugel describes the personality and character of Maharaja; 'without exaggeration, I must call him the most ugly and unprepossessing man I saw throughout the Panjab. His left eye, which is quite closed, disfigures him less than the other, which is always rolling about, wide open, and is much distorted by disease. The scars of the small-pox on his face, do not run into one another, but form so many dark pits in his greyish-brown skin; his short straight nose is swollen at the tip ; the skinny lips are stretched tight over his teeth, which are still good; his grizzled beard, very thin on the cheeks and upper lip, meets under the chin in matted confusion; and his head, which is sunk very much on his broad shoulders, is too large for his height, and does not seem to move easily. He has a thick muscular neck, thin arms and legs, the left foot and the left arm drooping, and small well-formed hands. ${ }^{\text {,ii }}$ Except one portrait of his young age, he is always depicted in long white beard, which also shows that the painters started to work for him lately. 'His long white beard and mustachoes give him a more venerable appearance than his actual age' (Osborne 1840, $82)$.

He is popularly shown facing right with a bright eye because, he lost his left eye by small-pox during his childhood but in some portraits, he is also shown facing left but mistakenly his left eye is shown uninfected. In the second half of nineteenth century, front face with both eyes, was also shown after European influences. During 1830 A.D., the front face of Maharaja was started to depict by native and European painters, but right profile of Maharaja was also remained popular with front face. 'A strange, though non-ideological, division between the foreign and Indian painters characterizes Maharaja Ranjit Singh's portraits. One could easily divide them between the "leftists" denoting European and the "rightists" represented by the Indian painters. This, in turn, could be attributed to the sides the painters took in the royal eye connection! There are any number of legends of Maharaja's presence being so radiant, so overpowering in its impact, that even his closest courtiers were not aware of his blind eye! ${ }^{\text {iv }}$

\section{B. Nimbus}

Nimbus can also be noticed around his head in some portraits by native artists. 'By showing Ranjit, nimbate, the artists were therefore breaking with Hill conventions and adopting a foreign 
device. Exalting Ranjit above the Rajput aristocracy of the Hills, they connected him, by implication, with the older houses of Rajasthan, invested him with Mughal like authority and thus endowed him with imperial majesty." Mughal-European influences appear behind the concept of nimbus to present the dignity of Maharaja.

\section{Hands}

Maharaja's hands are shown in different stances. Left hand often remains raised while conversing. A rosary of pearls in the hand of Maharaja shows his saintly nature and his firm faith in God while white handkerchief, wine-cup and wine-bowl show his fondness of drinking and his passionate nature. His resting hands on his upper thighs present a pose of comfort and stability of mind. In later portraits, an arrow in his hand shows him a warrior and victor of the mortal world. 'Ranjit Singh kept no eagles or hawks, which it was fashionable for big men in those days to display on their hands or wrists as a symbol of manliness and power. ${ }^{\text {vi }}$

\section{Legs}

The traditional style of sitting on floor became changed in Sikh portraits and due to the use of chairs and throne, the use of new postures painted by the native painters. While sitting on English chairs, Maharaja and his courtiers look like European officers. Contemporary European officials of Company as well as Maharaja were also habitual of sitting on chairs in relaxed crosslegged or straight-legged postures. Maharaja's legs remain in kneeling, straight, cross at knees and sometime one leg raised on knee or folded at knee with one leg straight. A variety of relaxed positions of legs were painted.

\section{E. Sitting position in group portrait}

In the court scenes, Maharaja always remains a central figure seated on golden throne or chair accompanied by the groups of his successors, nobles, courtiers and attendants. Golden throne is not a transportable object. So it can be seen only in Lahore court scenes in which Maharaja is seated to attend court assemblies. With the British impact, European chairs with native alterations became popular. Another reason may be that chairs can be easily move from one place to another, so these portraits are of outside assemblies held on terraces and camps. '....his (of Ranjit Singh) Court is remarkable; not an individual spoke without a sign, though the throng was more like a bazar than the court of the first native Prince in these times,' (Burnes Vol. III, 154) but instead of crowded scenes, some selected nobles were popularly painted in ideal form. In Lahore court scene; courtiers placed in the space according to their position, role and work in the court which always remain same because there was a fixed place for every noble for sitting on carpet, chair and also remained standing behind Maharaja.

In Lahore court scenes; a group of successors and favorite persons Kharak Singh, Sher Singh, Nau Nihal Singh and Hira Singh often shown seated on chairs behind Maharaja's golden chair or throne. Dogra brothers, Fakirs and various Sikh nobles and generals shown seated on carpet on the floor in front of Maharaja for discussing matters. Attendants and his chief minister remain standing behind him to follow his orders. In this way, the setting of court scenes emerged. Was it the real setting of Lahore court scene? Was the setting of courtiers in Lahore court divided into groups? Did some sit on chairs and others on carpet and some remained stand? In actual, Lahore court was always divided in groups; in which a group of successors of Maharaja always seated on chairs behind him, second group was of courtiers always seated on carpet in front of Maharaja and some courtiers remain busy in tally of accounts, last group of attendants and ministers standing behind Maharaja to follow his orders immediately. During his visit, Osborne noticed that, 'Rajah Sher Sing was seated on his (Maharaja's) right hand, and Rajah Heera Sing, 
his minister's son, upon his left, the only two individuals who are allowed a seat in his presence on

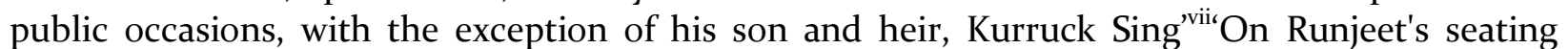
himself, his chiefs all squatted on the floor round his chair, with the exception of Dheean Sing, who remained standing behind his master., viii

Dari or thick cotton carpet always remained spread in court scenes. In Mughal-Rajput court scenes, a small square or rectangular carpet always spread over thick cotton carpet for dominating figure of ruler. But in Sikh portraits, round rug became more popular along with square carpet for dominating persons. Use of square silk canopies attached with golden-silver poles were also in fashion and can be seen outside assemblies of Sikh Maharaja.
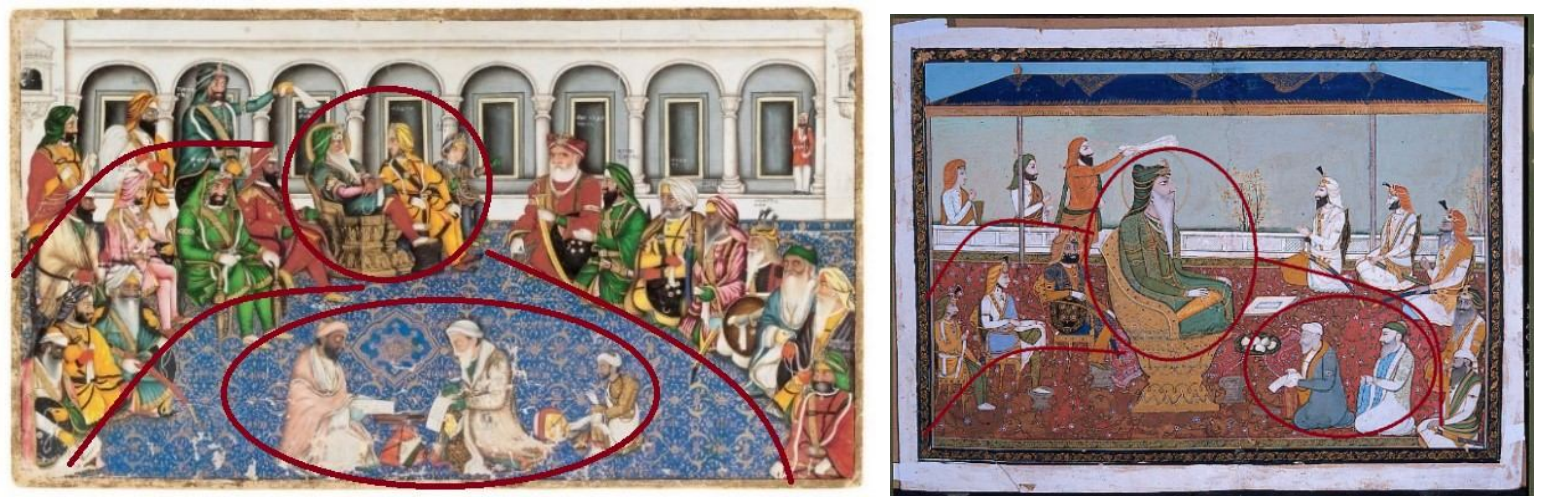

\section{Postures in equestrian portraits}

There are various portraits of Maharaja Ranjit Singh, mounted on horse accompanied by either only attendant or his infantry troops as he promoted infantry battalions under his service. He was fond of horse riding and often used to inspect his troops on horseback. In equestrian portraits, Maharaja always remains a central figure, and his troop accompanied him in a circular. '.......as soon as he mounts his horse, and with his black shield at his back, puts him on his mettle, his whole form seems animated by the spirit within, and assumes a certain grace, of which nobody could believe it susceptible. In spite of the paralysis affecting one side, he manages his horse with the greatest ease. ${ }^{\text {,ix }}$

The variation of equestrian postures often depends on the position of horse as well as changing style of comfortable postures during mounted on the horseback on different occasions by Maharaja. Maharaja remains stable and in straight position, if the horse is in stable position and with raised one leg inclined to move shows its willingness to move (figure 10). But the movement in the legs of horse does not remain a rider in straight posture and mounted person leans backwards (figure 11). Age of a mounted person also change the position of a rider. While mounted on horse; bridle in right hand and a white handkerchief were popularly used postures for hands of Maharaja. Sometimes a flower can also be seen in left hand.

Use of flat background is used to emphasis on Maharaja's figure in equestrian portraits. Like the court scenes, in equestrian portraits; figure of Maharaja remains in centre surrounded by infantry troops (figure 12). But the work of Pahari-Muslim and local painters emerged new variations in Maharaja's portraiture. Where, Pahari portraitists present Maharaja in hilly background as the sovereign of the hills (figures 10,11,12), on the other hand, European influences through Mughal-company style through the hands of Muslim painters are also clear in the form of 
'flattering, allegorical portraits' in which Maharaja is shown blessed with blissful supremacies (figure 13).

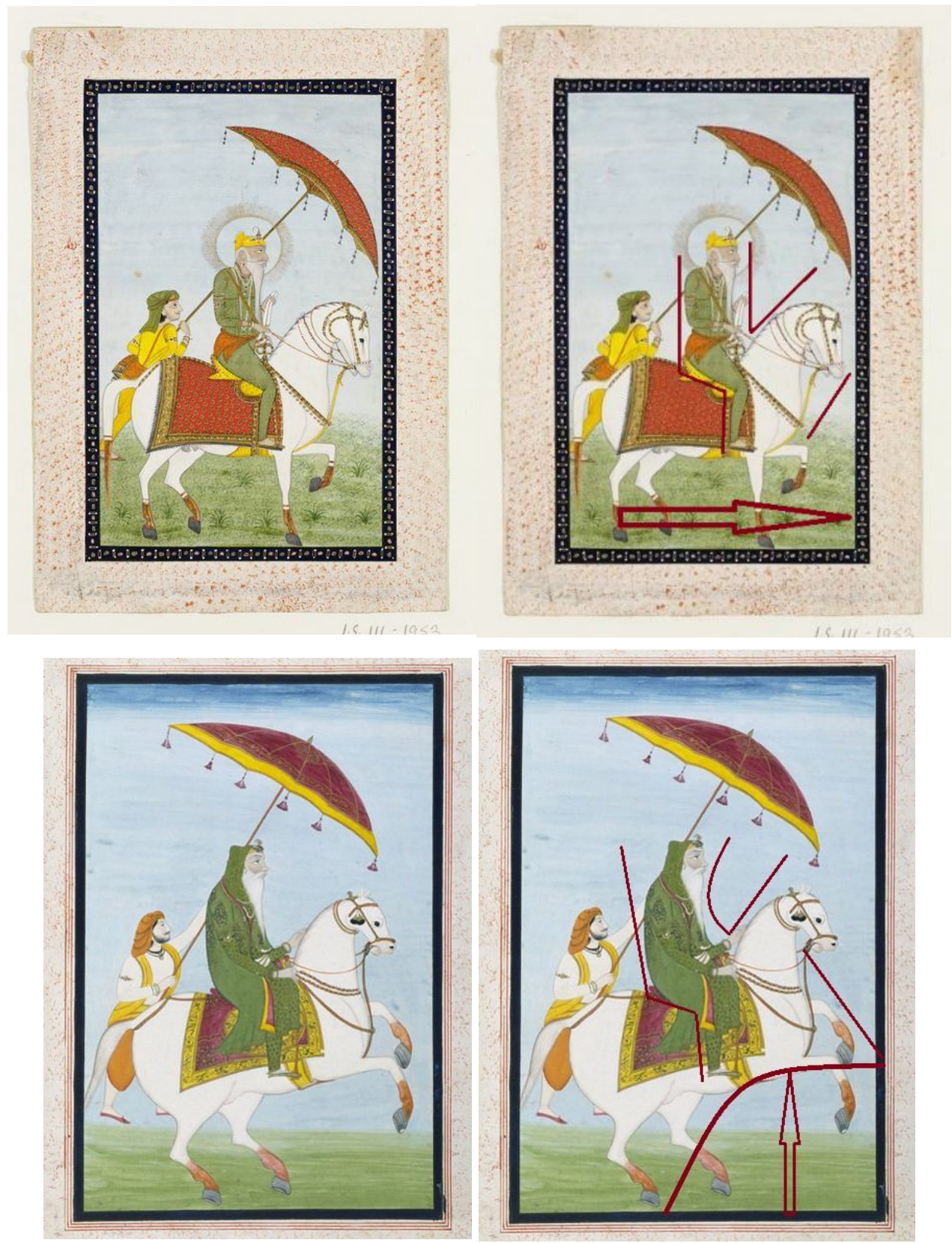

Figure 1o. Maharaja Ranjit Singh on horseback, ca. 1838 - ca. 1840, Museum no. IS.111-1953, Victoria and Albert Museum

Figure 11. Maharaja Ranjit Singh, ca. 1840, Museum no. IM.56-1936, Victoria and Albert Museum 


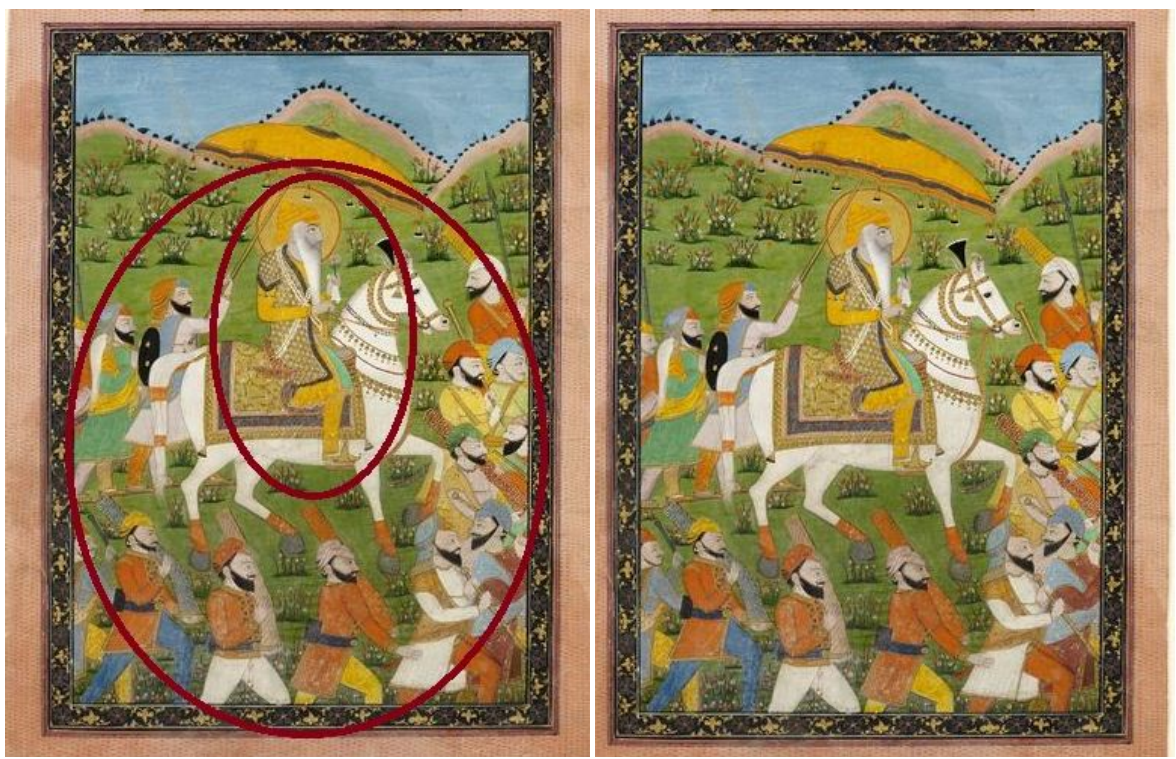

Figure 12. Maharaja Ranjit Singh, ca. 1835 - ca. 1840, Museum no. IS.282-1955, Victoria and Albert Museum
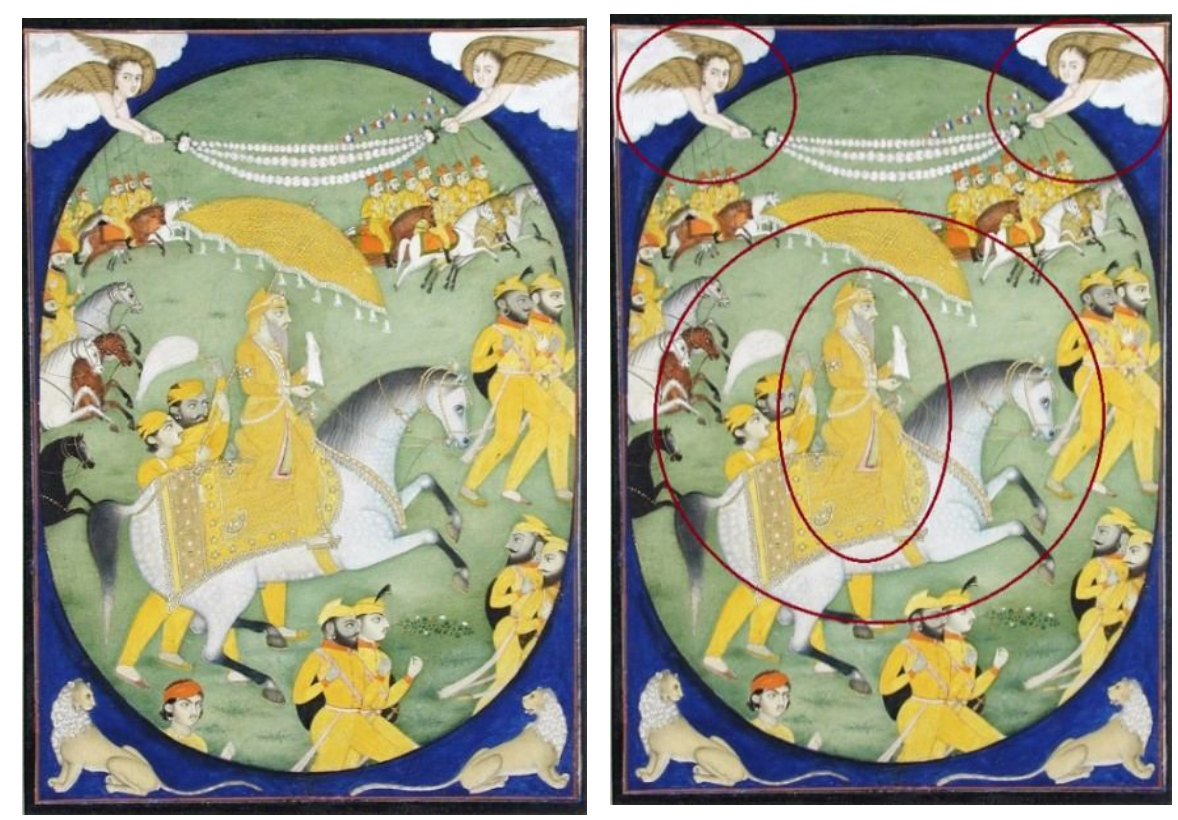

Figure 13. Ranjit Singh Equestrian in Saffron Robes, Accession no. 1990.1343, The San Diego Museum of art

\section{Posture in laying portrait}

For the first time, far from his casual as well as formal assemblies with courtiers and dignitaries, 'Lion of Punjab' is shown relaxing on his death bed with his empresses' consorts and female fellows and ready to go forward for his next journey (figure 14). The same and familiar portrait is applied for the miserable funeral scene by the painter. He appears in his well-known right profile, but the color of wrap is red, which is full of energy, as in the beginning of life, he preferred to wear bright colored garb. In the last scene of his life, Maharaja remains a central figure as always in his lifetime, but for the first time, his queens appear in the scene to accompany him in his last travel, except a scene in which his beloved was shown with him drinking liquor (figure 9). 

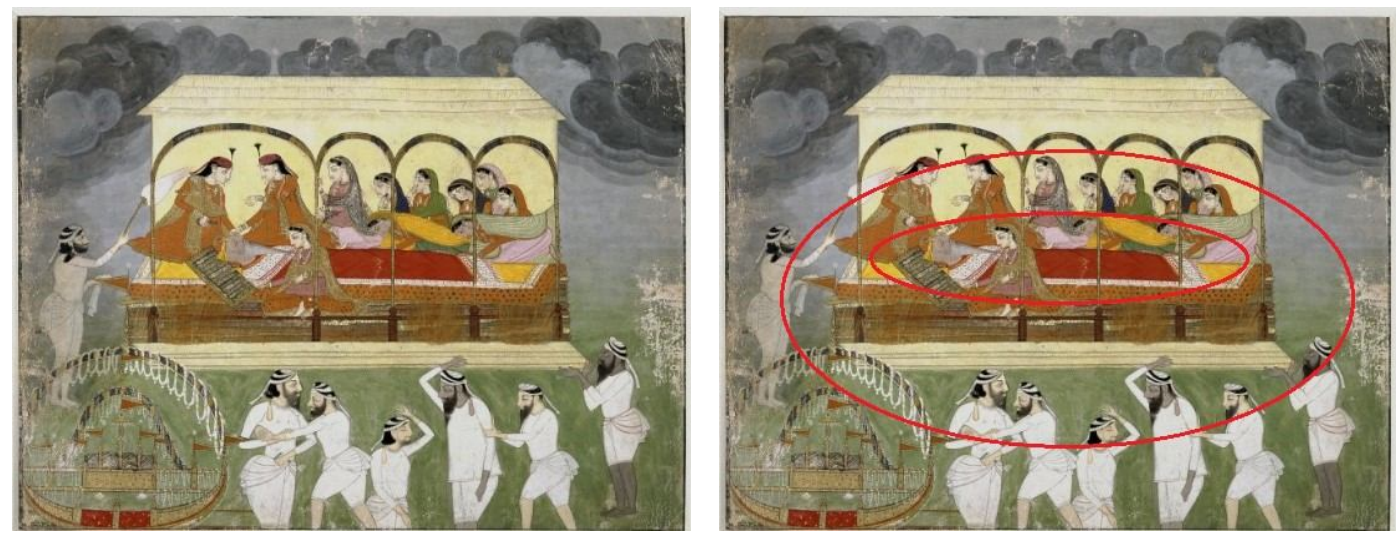

Figure 14. The funeral of Ranjit Singh, depicting suttee. Museum no. 1925, 0406, o.2, C. 1840, British Museum

\section{Styles of dress}

In portraits; Maharaja often seen in various shades of green, red, white and yellow colored dresses or contrast (figures 5, 6, 7,8) dresses of these colors. Probably, green (figures 2, 9, 10, 11), yellow (figures 12, 13) and white (figures 3) were the favorite colors of Maharaja. Fitted vest and tight trousers (figure 7, 10), kamarband or waist band and small conical turban of green and yellow were the dress of Maharaja. Sometimes a small wrap over conical turban used to spread over the shoulders. Over the fitted vest a long embroidered or simple gown and sometimes an embroidered jacket of brocade (figures 2, 6, 8, 11, 12) can be seen in the portraits. Earrings, bangles, strings of pearls and Koh-i-Noor on right arm, strings of pearls and a plume on turban.

'In earlier days he used to appear in divers ornaments; but this custom he has long discontinued, and I never saw him wear any embroidery, brocade, or rich ornament of any sort.' ${ }^{\text {x }}$ (figure 1) So green, yellow and white were used for his dresses because the color of Durbar was 'yellow, which is the favourite colour of the Seiks' (Burnes Vol. I, 14), 'yellow or green' (Hugel Charles 1845, 287), 'light green being the favorite colours of his court, and called Busuntee, or the colours of spring' (Prinsep 1834,164) but Emily Eden noted, 'Runjeet had no jewels on whatever, nothing but the commonest red silk dress ${ }^{\text {'xi ' }}$ Runjeet was dressed in a tunic of green shawls, lined with fur' (Burnes Vol. I, 23). 'His (Ranjit's) costume always contributes to increase his ugliness, being in winter the colour of gamboge, from the Pagri (the turban or Sikh cloth, on his head,) down to his very socks and slippers. The Sikh pagri consists of a long narrow piece of linen, in which the hair is wrapped up; and it is so fastened either in the front or a little on one side, that one cannot see either end or knot. It lies down smooth on the head, one end hanging half way down the back. Ranjit Singh hides this end under his upper garment. The Angraka (coat) is tied over the chest, and reaches to the knee, and the trousers fall in many folds down to the ancle. Over the whole is worn a mantle lined with skins. The entire costume is, as I have said, of yellow Pashmina, green being worn sometimes by him, but not commonly. In summer he wears white muslin. At the festival of the Basant, he was particularly disfigured by the straw-coloured dress he wore with a slight intermixture of green in it. ${ }^{\text {xii }}$ 'He used to dress simply in plain silk or cashemere colth, shunning gaudy robes except on very special occasions when they were indispensable. He was similarly modest in wearing jewellery. Generally he wore none; but when he received foreign visitors, he would wear a row of pearls or a string of diamonds. It was only on very important state occasions that the Koh-i-Noor (after he had acquired it) was displayed on his person in addition to one or both of these. ${ }^{\text {'iii }}$ 


\section{Conclusion}

Rajput-Mughal inspirations and models were used for the portraits of Maharaja in the beginning but in later times, with the increasing impact of Maharaja, his particular identifiable habits and postures became known to all. Group portraits of Maharaja with his brilliant courtiers are of 1830s, when Dhyan Singh Dogra became chief minister of Maharaja. Far from crowd of Mughal and Rajput scenes; in Sikh court selected courtiers are painted. English culture also influenced Sikh lifestyle. After 1830s, the political and social position and secular personality of Maharaja overwhelmed everyone. Maharaja's beard often remains white, which signifies later years of his life. Scene from the later mature court in which Dogra-Fakir and Sikh were undivided part. Carpet portrait of Indian tradition influenced Maharaja's portrait during first decade of nineteenth century but through the use of chairs, carpet portraits are done in less number replacing traditional style of sitting on carpet or low beds, which also separate Sikh Lahore court scene from Mughal-Rajput court. With the beginning of 1830s, frontal face of Maharaja was also started to paint. The impact of European influences in the form of enlargement of figures are also clear on Sikh portraits. In portraiture, the dignity of Maharaja and his impact over nature, his military heroism, and his immense physique over populace, whether seated on a throne, or mounted astride a horse in various poses were presented by the native as well as western painters.

\section{References}

\footnotetext{
${ }^{\mathrm{i}}$ Waheeduddin, Fakir Syed. (1965). The real Ranjit Singh, Lion art press, (Karachi) Ltd., Pakistan. 25

ii Singh, Khushwant. (1962). Ranjit Singh, Maharajah of the Punjab, 1780-1839', George Allen and Unwin Ltd., London. 47

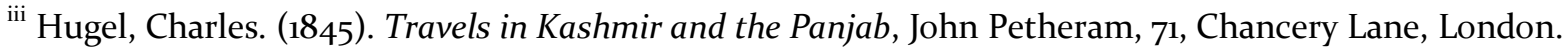
380

${ }^{\text {iv }}$ Singh, Man Mohan. Changing faces of Maharaja Ranjit Singh in portraiture, Appreciation of creative arts under Maharaja Ranjit Singh, Marg, Bombay, p. 73

${ }^{v}$ Archer, W. G. (1966). Paintings of the Sikhs, HMSO, London. 38

${ }^{v i}$ Waheebduddin, Fakir Syed. (1965). The real Ranjit Singh, Lion art press, (Karachi) Ltd., Pakistan. 166

vii Osborne, W. G. (1840). The court and camp of Runjeet Sing, Henry Colburn, Publisher, London. 72

viii Osborne, W. G. (1840). The court and camp of Runjeet Sing, Henry Colburn, Publisher, London. 73

${ }^{\text {ix }}$ Hugel, Charles. (1845). Travels in Kashmir and the Panjab, John Petheram, 71, Chancery Lane, London. 380

${ }^{\mathrm{x}}$ Hugel, Charles. (1845). Travels in Kashmir and the Panjab, John Petheram, 71, Chancery Lane, London. 380

${ }^{x i}$ Eden, Emily. (18660). Up the country, Vol. I, Richard Bentley, New Burlington Street, London. 284

${ }^{\text {xii }}$ Hugel, Charles. (1845). Travels in Kashmir and the Panjab, John Petheram, 71, Chancery Lane, London. 380

xiii Waheeduddin, Fakir Syed. (1965). The real Ranjit Singh, Lion art press, (Karachi) Ltd., Pakistan. 25
}

Gurdeep Kaur, Research scholar of Fine Arts, Lovely Professional University, Phagwara, India. Email.gurdeepkaur121@yahoo.in.

Dr. Rohita Sharma, Assistant professor, Lovely Professional University, Phagwara, India. Email. rohita.19359@lpu.co.in. 